\title{
Prevajanje ideoloških referenc: primer Alana Forda
}

Ana Beguš

Fakulteta za humanistične študije Univerze na Primorskem, Oddelek za uporabno jezikoslovje, Titov trg 5, 6000 Koper, Slovenija https://orcid.org/0000-0001-5279-7005 ana.begus@gmail.com

Članek analizira prevajanje ideoloških referenc v treh številkah italijanskega stripa Alan Ford. Strip je v hrvaščino prevedel Nenad Brixy, prevajalec, pisec in urednik pri zagrebškem časopisu Vjesnik, ki je tudi predlagal njegovo objavo v hrvaščini. Brixyjev prevod, ki je v nekdanji Jugoslaviji postal legendaren predvsem zaradi humorja, je relativno svoboden in prej kulturna priredba kot zvest prevod. Analiza treh izbranih epizod kaže, da so vse ideološke reference $v$ dveh epizodah, ki so bile objavljene v istem zaporedju kotv italijanskem izhajanju, prirejene, medtem ko je prevod tretje analizirane številke, Formule, ki je bila objavljena šele kasneje, znatno bolj dobeseden, zato ga ne moremo pripisati Brixyju, četudi je v kolofonu tudi pri tej številki naveden kot njegov prevajalec.

Ključne besede: literarni prevod / priredba / cenzura / samocenzura / ideologija / italijanska književnost / strip / Alan Ford / prevodi v hrvaščino

Alan Ford je strip, ki je na področju nekdanje Jugoslavije prerasel v samostojen kulturni fenomen. Izvorno je italijanski, plod dela tandema Magnus (Roberto Raviola) - Max Bunker (Luciano Secchi) in del tradicije t. i. črnega stripa (fumetto nero), ${ }^{1}$ ki se razvije v Italiji v drugi polovici 20. stoletja. Osrednji junaki stripa so člani tajne vohunske skupine TNT, ki imajo sedež $\mathrm{v}$ prostorih neugledne cvetličarne $\mathrm{v}$ New Yorku in ki jih vodi skrivnostni Numero Uno (Številka Ena ali Broj Jedan v hrvaškem prevodu). Člani skupine - klasični antijunaki in družbeni marginalci, ki se ne morejo ali nočejo integrirati v sistem, ter New York oz. ZDA kot prototipna kulisa zahodnega življenja, predstavljajo odlično izhodišče za duhovito kritiko družbene razslojenosti, skorumpirane oblasti ter absurdnosti sistema, ki se nazorno kaže skozi tipične alanfordovske izreke, kot so npr. »bolje je živeti sto let kot milijonar kot sedem dni v bedi«, »kdor želi zmagati, ne sme izgubiti«, »kupi dva, plačaj tri« ipd.

\footnotetext{
${ }^{1}$ Več o semiotski analizi stripa Alan Ford glej Gržina.
} 
Strip je v izvirniku začel izhajati leta 1969; preveden je bil v različne evropske jezike, med drugim $\mathrm{v}$ francoščino, danščino, španščino, a so ga po nekaj številkah povsod, razen $v$ Italiji in kasneje v Jugoslaviji, prenehali izdajati, saj ni naletel na večji odmev ali prodajni uspeh. V srbohrvaščini je prvič izšel leta 1970 v prevodu Nenada Brixyja, od takrat izhaja kontinuirano v različnih prevodih in ponatisih. Preveden je bil tudi v slovenščino (51 številk), makedonščino (9 številk) in albanščino (3 številke), vendar ti prevodi niso doživeli takega odziva kot hrvaški. Pri tem je treba dodati, da Brixy ni bil le prevajalec, ampak tudi glavni pobudnik za odločitev, da se strip prevede: kot urednik je bil namreč zaposlen pri stripovski redakciji časopisa Vjesnik ter je poslovno pogosto odhajal $\mathrm{v}$ Italijo in od tam prinašal različna gradiva, med drugim tudi Alana Forda, ki mu je bil zelo všeč; zato ga je kot član uredništva Vjesniku tudi ponudil v prevod.

Razloge za uspeh stripa v nekdanji SFRJ gre najprej deloma iskati v dejstvu, da so z izdajanjem Alana Forda kljub začetnim slabšim odzivom vztrajali samo v Italiji in v Jugoslaviji, v ostalih evropskih državah pa so izdajanje ukinili že relativno zgodaj, po izdanih petih ali šestih številkah. Lahko pa se strinjamo z Džamićem, ki za uspeh stripa navaja sedem razlogov: 1 . forma commedie dell' arte $^{2}$, po kateri se je zgledoval Bunker, in ki je po njegovem mnenju tudi na Balkanu od nekdaj živa, 2. dejstvo, da je nadrealna farsa kot atmosfera stripa na Balkanu način življenja (na kar kaže tudi izvirna kulturna produkcija na področju nekdanje Jugoslavije), ${ }^{3}$ 3. satirična kritika kapitalizma, 4. identifikacija $\mathrm{z}$ liki v stripu kot $\mathrm{z}$ "nepopravljivimi diletanti« v disfunkcionalni družbi, ki se iz težav izvlečejo bolj po srečnem naključju kot čem drugem, 5. univerzalno hvaljen Brixyjev prevod, 6. Magnusova mehka in elastična risarska linija, ki učinkovito izraža zelo različna čustvena stanja protagonistov, ter 7. kulturna sorodnost med Italijo in Balkanom (Italija kot nekakšen zahodni Balkan) (glej Džamić).

Manić med razlogi za uspeh stripa navaja relativno odprt jugoslovanski trg v 70. letih 20. stoletja, praktičen format (ki se ga je dalo brati tudi pod šolskimi klopmi), poceni produkcijo, ki je omogočala cenovno dostopnost stripa, ter vizualno prepoznavnost likov. A tudi zanj so najpomembnejši žanr in Brixyjev prevod, predvsem pa naslovni

${ }^{2}$ Za podrobnejšo utemeljitev sorodnosti Alana Forda s formo commedie dell'arte, za katero so značilni značajski tipi (»tipi fissi«), glej Džamić 21-44.

${ }^{3} \mathrm{Ne}$ le, da so liki, reference in citati iz stripa v nekdanji SFRJ postali del kulturnega imaginarija, pač pa je fenomen stripa dejansko prešel meje prevoda, saj je $\mathrm{z}$ uporabo in adaptacijo izhodiščnega vizualnega gradiva nastala celo izvirna številka (oziroma psevdoprevod) Skupina TNT in J. B., ki je kritično tematizirala jugoslovansko samoupravljanje. 
junak Alan Ford kot reven, a pošten in dobronameren mladenič, ki je utelešal takratne ideale in vrednote ljudi:

Menim, da Alan Ford našim bralcem s preprostostjo ljudske pripovedke pomaga razumeti svet, in sicer z metaforično subtilnostjo, ki je v popularnem stripu redka. [...] je lik, o katerem so nam pripovedovali naši stari starši in starši, nekdo, ki je reven, sirota, ki ima le malo oblek, ki doživlja absurdne situacije, a naivno in nedolžno ohranja upanje in sanje, zaradi katerih gre dalje. Nikoli ne bom pozabil epizode Alana Forda, ki sem jo bral pred tridesetimi leti: pripovedovala je o bogatem otroku, ki je imel celo vojsko kositrnih vojakov, za celotno zbirko mu je manjkal le eden - in ravno tistega je imel nek reven otrok. (Panturo)

\section{Brixyjev prevod kot sestavni del kultnosti stripa}

Pri Brixyjevem prevodu bralci in komentatorji hvalijo predvsem komično teatralnost jezika, odličen humor ter ustvarjalno prirejanje $\mathrm{z}$ ustvarjanjem izvirne humorne in metaforične zaznamovanosti v prevodu. Zaradi njegovega ustvarjalnega doprinosa bralci stripa Brixyja štejejo za tretjega avtorja, ${ }^{4}$ o čemer priča tudi dejstvo, da so mu leta 2015 v rojstnih Varaždinskih Toplicah postavili spominsko ploščo.

Eden od razlogov za komični učinek Brixyjevega prevoda naj bi bil izrazito formalen in celo rahlo vznesen jezik, uporabljen $\mathrm{v}$ prevodu, nekakšna »umetna in teatralizirana hrvaščina, ki je nihče ni govoril« (Manić v Patruno), ki je v jasnem neskladju z vizualnimi in vsebinskimi elementi stripa. Osrednji liki Alana Forda so družbeni marginalci, tipični nosilci obrobnega sociolekta (Skubic) - ki pa govorijo kultivirano, govorico družbene elite, in s tem izkazujejo govorno imenitnost, ki ustvarja komičen kontrastni učinek z njihovo siceršnjo podobo in življenjskim stilom. Konkretni prevodni ekvivalent na sociolektalni ravni je "purgerščina" , 5 malomeščanska govorica Zagreba, kjer je Brixy živel in delal, kar je še potenciralo že izhodiščno farsični duh stripa. Kot pravi Džamić, je knjižna (»čista», "visoka») hrvaščina »v Srbiji [...] v stripu učinkovala še bolj burkaško tudi zato, ker smo se otroci v igri pačili v tem jeziku, ko smo se igrali purgerje. Za nas je bil to jezik farse

${ }^{4} \mathrm{Z}$ vidika teorije prevajanja tu pridemo do izmuzljive in pogosto tematizirane meje med avtorjem in prevajalcem: prevajalec je v dominantni praksi (deloma pa tudi teoriji) prevajanja definiran kot sekundaren avtorju, v enakovreden ali celo nadrejen položaj je postavljen le izjemoma.

${ }^{5}$ T. i. "purgerski«, zagrebški kultivirani sociolekt z elementi arhaizma (imenovan tudi "starozagrebški«), ki se povezuje z malomeščansko vzvišenostjo (v odnosu do ruralne okolice) ipd. 
in neke druge realnosti. Burkaške. Takšen učinek je imela tudi hrvašcina Alana Forda na jugoslovanskih trgih."(Horvat)

Pohvalne ocene prevoda se sicer v večji meri osredotočajo na jezik in duhovitost prevoda kot na tehnične prevodne kriterije, npr. na kredibilen prenos vsebine $\mathrm{v}$ ciljni jezik in prevajanje morebitnih ideološko problematičnih mest $\mathrm{v}$ izvirniku, kot so satirični komentarji takratnih realsocializmov ipd. Ob strinjanju, da je Brixyjev prevod dejansko jezikovno in slogovno izjemen, smo opravili tudi primerjalno analizo izvirnika in prevoda na primeru treh izbranih epizod: dveh izdanih v istem zaporedju izhajanja kot v izvirniku (Una gita a San Guerreta ter Un voto per Notax) in ene (Le Formule), ki je bila izpuščena ter prevedena in objavljena šele kasneje.

\section{Cenzura v prevajanju}

Vprašanje ideološke zaznamovanosti besedila, ki je v prevajalski praksi pogosto predmet cenzure ali samocenzure (Seruya in Lin Moniz), je eno osrednjih vprašanj teorije prevajanja, posebej njene kritičnoteoretske obravnave (Venuti; Baker). Vsako besedilo odraža določeno kulturo ali ideologijo skozi jezikovno rabo, ki reflektira nabor uporabnikovih predpostavk, prepričanj in nazorov (Hatim in Mason). Prevajalci so kot medkulturni posredniki pri svojem delu pogosto postavljeni ne le $\mathrm{v}$ položaj med dvema jezikoma in kulturama, pač pa v samo srž razlike in potencialnega konflikta med dvema divergentnima diskurzoma, dvema različnima, pogosto nasprotujočima si ideologijama. V tej situaciji lahko po načelu zvestobe $\mathrm{v}$ ciljno besedilo prenašajo ideološko zaznamovanost izvirnika ali pa se iz različnih razlogov odločajo za vsebinsko poseganje $\mathrm{v}$ prevod in njegovo spreminjanje.

$\mathrm{Z}$ vprašanjem ideološke zaznamovanosti besedila je tesno povezano tudi vprašanje cenzure. Ta običajno predstavlja zunanji poseg v besedilo z namenom izločanja ali izkrivljenja izvirne, domnevno sporne vsebine. Vendar lahko pojem razumemo širše: po Bourdieuju je cenzura strukturna $\mathrm{v}$ smislu tega, da je kot diskurzivna omejitev prisotna v vsakem besedilu in del habitusa določenega ( $\mathrm{v}$ našem primeru prevajalskega) polja, torej ponotranjenja pravil igre (glej Bourdieu). Ta implicitna oblika cenzure se velikokrat kaže kot samocenzura ali kot "preventivna cenzura" (Kocijančič Pokorn). V tem smislu lahko cenzuro razumemo kot kontinuum, ki sega od eksplicitne do implicitne (Tymoczko). Kuhiwczak gre pri tem celo tako daleč, da predlaga, da siceršnje pojme, ki opisujejo težavnost pojma ekvivalence v prevajanju, kot so manipula- 
cija, ponovno pisanje, potujitev in podomačitev, enostavno zamenjamo z izrazom cenzura (glej Kuhiwczak). Vsako besedilo se v procesu prevajanja $\mathrm{v}$ drug jezik neizogibno prilagaja novim okoliščinam in namenu, pri čemer prevajalec lahko zdrsne tudi v vlogo razsodnika ali cenzorja, ki odloča o tem, kaj sme v ciljno kulturo in kaj ne; posamezne odločitve prevajalcev pa v tem procesu nihajo od "kolaboracije do upora" (Tymoczko) in so pogosto bolj podrejene posameznim narativom kot krovnim ideološkim pozicijam ter odvisne od konkretnih okoliščin prevajalskega naročila in prevajalčevega statusa in suverenosti $\mathrm{v}$ njih (Baker). Samocenzura se v tem smislu lahko skrije oziroma umesti v okvir prevajalčeve prevajalske strategije in praviloma ni dokumentirana kot $\mathrm{v}$ primeru zunanjega cenzurnega poseganja v prevod, kar otežuje njeno dokazovanje.

Prevladujoči vrsti cenzurnega poseganja $\mathrm{v}$ prevod sta predvsem izpust spornega elementa ali pa celo celotnih epizod v primeru serijskih izdaj ter vsebinsko prilagajanje prevoda $\mathrm{v}$ skladu $\mathrm{z}$ ideologijo ciljne kulture. Cenzura in samocenzura sta inherentni vsakemu političnemu režimu, v prevodoslovju pa sta tudi dobro popisani (za Italijo glej npr. Rundle, za Nemčijo Sturge, za Španijo Crespo, za Sovjetsko zvezo Sherry, Censorship, in Sherry, Discourses; za Kitajsko Zaixi Tan; in za SFRJ Kocijančič Pokorn). Konkretnih podatkov o morebitnem cenzuriranju stripa Alan Ford ni mogoče najti, z izjemo nekaj izjav v intervjujih, ki pa niso najzanesljivejše. Prav tako ni mogoče najti prevajalčevih pojasnil o vsebinskem prilagajanju prevoda; dopuščamo lahko možnost samocenzure ali pa idiosinkratskih odločitev prevajalca, ki niso odvisne od zunanjih vzrokov.

Iz izhodiščne numeracije stripa so v prevodu izpuščene 10. epizoda (Formule; analizirana v nadaljevanju), 38. epizoda (Godišnji odmor), 39. epizoda (Dobra stara vremena), 40. epizoda (Ekologija), 43. epizoda (Novogodišnja proslava), 50. epizoda (Tako je nastala grupa TNT), 86. epizoda (Hladni pol), 125. epizoda (Viša rasa/Otok mračnjaka) in 180. epizoda (Olimpijski plamen) (glej Alan Ford - Piratska). Prva izdaja, v kateri so bili prevodi Alana Forda izdani po izhodiščnem vrstnem redu, je dejansko ponatisna izdaja Alan Ford Klasik, ki je izhajala od leta 2004 dalje.

$\mathrm{Ni}$ tudi jasno, ali so bile omenjene epizode sploh prevedene po vrstnem redu nastanka izvirnikov ali so jih prvič prevedli šele kasneje: omenjene izdaje naj bi namreč krožile kot piratske izdaje, o katerih pa ni moč pridobiti več podatkov o času izida. 10., 38., 39. in 40. epizoda so izšle v ponatisu Alan Ford Klasik (leta 2004), 86. in 180. epizoda sta uradno izšli leta 2001 v Srbiji, 125. epizoda, ki je v piratski izdaji izšla 
z naslovom Viša rasa, pa je bila kasneje pod naslovom Otok mračnjaka uradno natisnjena $\mathrm{v}$ seriji MAXIPLUS.

$\mathrm{V}$ spodnji razpredelnici navajam pregled prevodov spornih epizod glede na izdajo in približno leto objave:

\begin{tabular}{|c|c|c|c|c|c|c|c|}
\hline 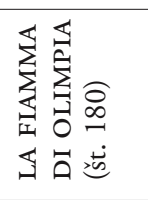 & - & - & - & - & - & - & 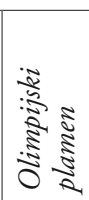 \\
\hline 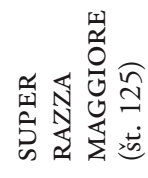 & - & 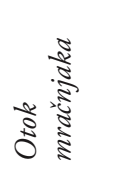 & - & - & 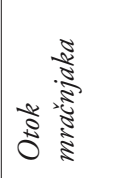 & - & 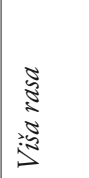 \\
\hline 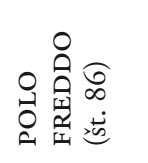 & - & $\gamma$ & - & - & - & - & 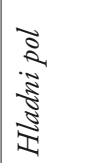 \\
\hline 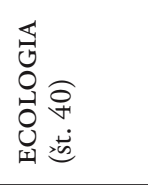 & - & 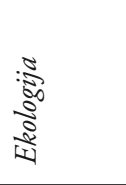 & 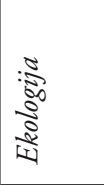 & 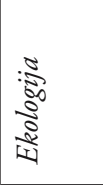 & 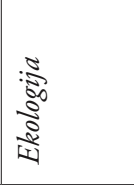 & - & 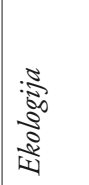 \\
\hline 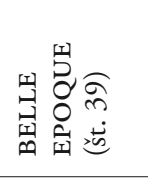 & - & 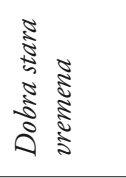 & 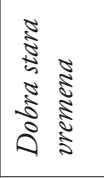 & 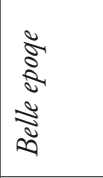 & 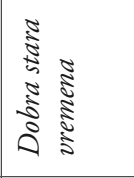 & 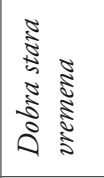 & 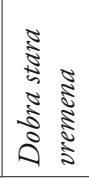 \\
\hline 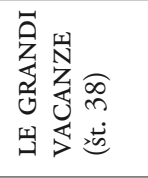 & - & 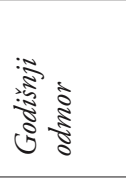 & 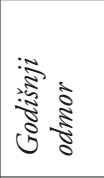 & 离 & 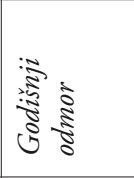 & 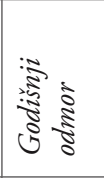 & 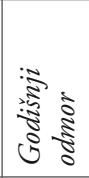 \\
\hline \multirow[t]{2}{*}{ 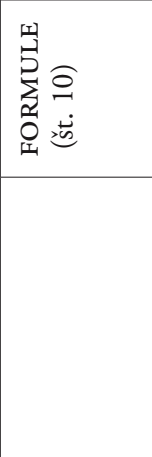 } & - & - & है & है & है & है & 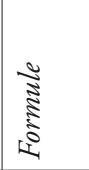 \\
\hline & 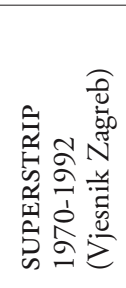 & 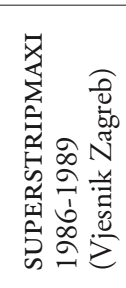 & 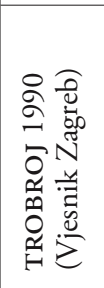 & 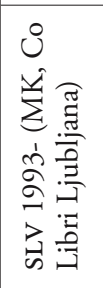 & 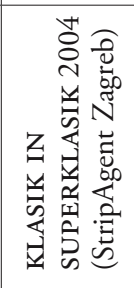 & 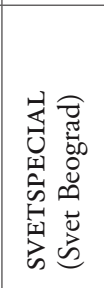 & 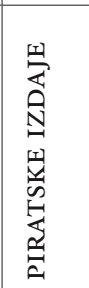 \\
\hline
\end{tabular}

Razpredelnica 1: Posamezne izdaje stripa 
Zastavlja se vprašanje, ali so bili prevodi spornih epizod opravljeni še pred razpadom SFRJ ali po njem in izdani kot piratske izdaje, $\mathrm{v}$ povezavi $s$ tem pa seveda tudi, kdo jih je prevedel in kako so se distribuirale. Aleksander Buh ${ }^{6}$, stripovski poznavalec in lastnik trgovine $s$ stripi Strip.art.nica v Ljubljani, pravi, da so piratske izdaje obstajale že pred letom 1990: tiskane so bile ilegalno in v bistveno manjših nakladah (tudi manj kot 100 izvodov), informacija o njih se je širila ustno, epizode pa so si ljubitelji stripa potem posojali med seboj. Hkrati so posamezne epizode, ki niso izšle v redni seriji (Superstrip), izhajale tudi kot priloge različnih drugih revij in so jih bralci poiskali tam; torej so bile potencialne sporne epizode lahko tudi uradno objavljene še pred razpadom SFRJ (Buh). Uradno naj bi bile objavljene šele leta 2001 in 2003 v Srbiji (Alan Ford - Piratska).

Pri vseh prevodih, tudi tistih najprej izpuščenih, je kot prevajalec naveden Brixy. Formule, prva epizoda, ki je bila v prevodu izpuščena in ki jo $\mathrm{v}$ nadaljevanju tudi analiziram, je uradno gotovo izšla že prej, in sicer pri Vjesniku 9. 3. 1990, po navedbah Buha pa je najbrž obstajal tudi piratski izvod, ki je temeljil na prevodu, nastalem še pred tem.

$\mathrm{V}$ povezavi $s$ tem se zastavlja vprašanje avtorstva prevoda: tudi Bernard Radovčić, uradni izdajatelj ponatisa stripa v seriji Alan Ford Klasik, je namreč ustno potrdil informacijo, da je avtor vseh prevodov v seriji, tudi Formul, Brixy (Buh). A bi bilo glede na to, da je Brixy umrl leta 1984, to mogoče le, če bi Brixy prevod pripravil že za piratsko izdajo in bi bil ta prevod potem uporabljen tudi za objavo v Vjesniku leta 1990 ter za ponatis v seriji Alan Ford Klasik, česar pa analiza prevoda $\mathrm{z}$ vidika prevajalske strategije ne potrjuje (glej nadaljevanje članka): verjetnejša se zdi možnost, da je te epizode prevedel neki drug prevajalec, ki poimensko ni nikjer naveden, s čimer se ohranja brixyjevski mit kultnega prevoda. Buh navaja tudi, da naj bi strip po Brixyjevi smrti leta 1984 prevajal njegov sin Davor.

Podrobnejši pregled samocenzuriranih mest $\mathrm{v}$ posameznih epizodah pokaže, da se pri posegih $\mathrm{v}$ prevod ni cenzuriralo le mest, ki bi bile kritične do realsocializmov ali socializma na splošno, pač pa vse elemente, ki bi lahko predstavljali morebitno ideološko kontaminacijo, npr. vse reference, pa četudi izrazito kritične, na fašizem ali rasizem. Najočitnejša mesta ideološkega govora so po navadi položena $\mathrm{v}$ usta različnih gostujočih likov: raznih diktatorjev, ameriških kapitalističnih agentov, ideologov ene ali druge strani ipd. Ideološko sporen pa je tudi

${ }^{6} \mathrm{Na}$ tem mestu se Aleksandru Buhu zahvaljujem za prijazno pomoč in informacije glede piratskega in uradnega izhajanja stripa. 
vsaj eden od glavnih junakov: Grunf, nekdanji nemški vojak, ki je sicer prikazan kot dobronameren, a socialno neroden član skupine TNT, ki zato pogosto spontano prenaša ideološke elemente (npr. dvignjena roka $\mathrm{v}$ nacistični pozdrav, pozdravljanje $s$ Heil Hitler, različne verbalne intervencije ipd.). Ob tem je zanimivo, da tu cenzura ni povsem dosledna: na več mestih $\mathrm{v}$ prevodih se ohranjajo nekatere reference, katerih izhodiščna fašistična konotacija pri prevajalcu očitno ni bila prepoznana. Eno očitnejših takšnih mest je npr. znana Grunfova parola "tko vrijedi, leti, tko leti, vrijedi, tko ne leti, ne vrijedi«, ki je dejansko minimalna parafraza fašističnega slogana »chi vola vale, chi non vola non vale, chi vale e non vola è un vile« (»kdor leti, velja, kdor ne leti, ne velja, kdor velja in ne leti, je ničvrednež «), katerega prvi del je bil izpisan na pročelju monumentalnega atrija ministrstva za letalstvo fašistične Mussolinijeve vlade. ${ }^{7}$

Da je bil izvirnik ne le jezikovno, pač pa tudi vizualno spreminjan, dokazuje primer iz epizode Traži se Alex Barry (Alex Barry non c'è più, št. 6) (Alan Ford - Cenzura). V enem od prizorov v izvirniku se pojavljajo eksplicitni nacistični simboli: na zidu visi Hitlerjeva slika, pod njim pa napis "Allo zio Adolfo« (Stricu Adolfu); poleg nje je na zidu napis "Noi tireremo diritto" (ita. "streljali bomo naravnost «; iz fašistične pesmi, ki so jo prepevali med italijanskim kolonialnim osvajanjem Etiopije), z inicialko M (najverjetneje Mussolini). V prvem prevodu je Hitler na sliki zamenjan z raketo (najbrž skladno z Grunfovo obsedenostjo s tehniko), pentlja z napisom pod njo je izbrisana oz. spremenjena $v$ zidake, prav tako tudi inicialka $M$, napis "Noi tireremo diritto« pa v ime skupine - TNT. V drugi, Borgisovi izdaji, pa fašistični simboli in napisi niso cenzurirani; pri čemer napis na pentlji ni preveden, fašistični slogan je preveden dobesedno ( $(M i$ ćemo vući ravno«), a je pri ciljnih bralcih najverjetneje nerazumljiv, ostaja tudi inicialka M. V Strip-Agentovi izdaji iz leta 2004 (Alan Ford Klasik) so prav tako ohranjeni vsi fašistični simboli, napis "Noi tireremo diritto" pa je preveden kot »Pucat ćemo u glavu«.

\footnotetext{
${ }^{7}$ Fasciniranost fašizma nad tehnologijo je znana in popisana, glej npr. Lehmann.
} 


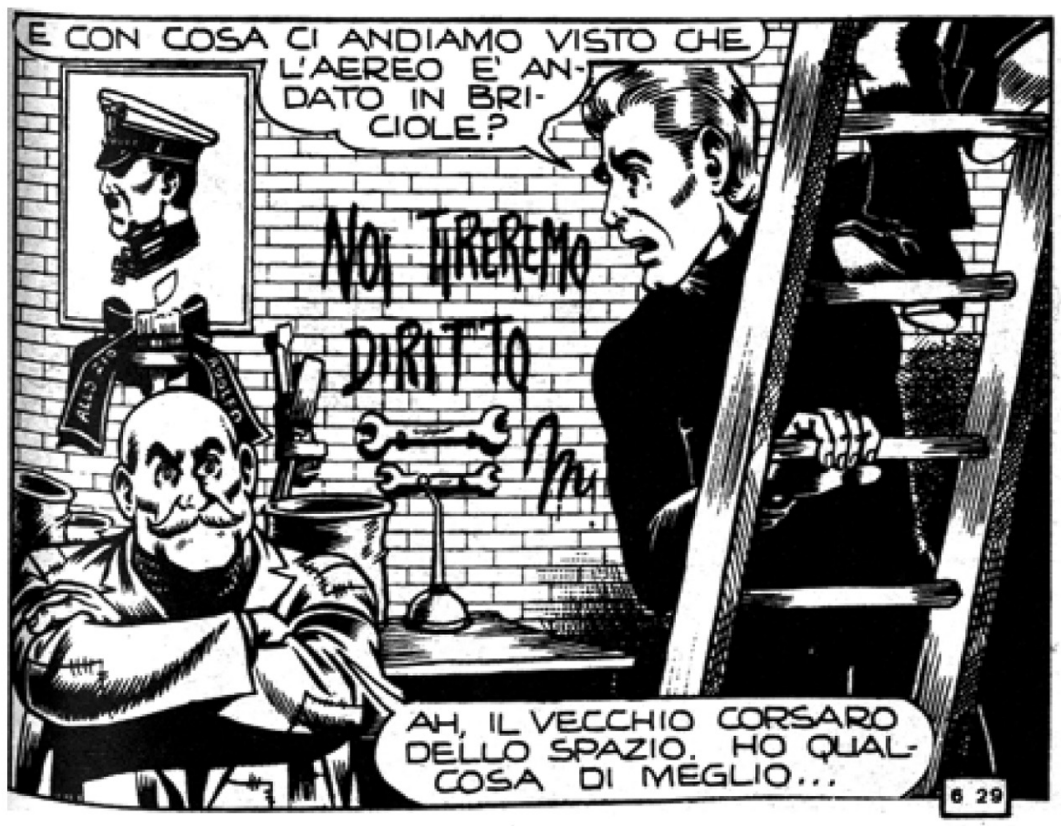

Slika 1: Sporna sličica iz epizode Alex Barry non c’è più

\section{Analiza prevoda izbranih epizod}

$\mathrm{V}$ nadaljevanju analiziramo prevod treh izbranih epizod iz zlatega obdobja Alana Forda, tj. prvih 75 številk. Gre za epizode in prevode Ucviljeni diktator (v izvirniku: Una gita a San Guerreta, št. 7), (Ne) glasajte za Notaxa (v izvirniku: Un voto per Notax, št. 16) ter Formule (v izvirniku: Formule, št. 10), vsi trije po prevodu iz serije Alan Ford Klasik. Tretja epizoda, Formule, je bila iz izhodiščne serije Super Strip izpuščena in po dostopnih podatkih prvič uradno objavljena v trojni številki leta 1990 pri Vjesniku. Besedila tega prevoda nisem uspela pridobiti, zato ne morem vedeti, ali gre za ponatis, za ostali dve epizodi pa predpostavljam, da sta ponatisa prvega prevoda iz serije SuperStrip.

Iz vsake od epizod so bili izbrani za analizo relevantni izseki; ti izseki so bili nato iz italijanskega izvirnika in hrvaškega prevoda precej dobesedno prevedeni v slovenščino, na tej osnovi pa je bila opravljena primerjalna analiza med obema različicama. Splošne ugotovitve iz analize so povzete pod tabelo $\mathrm{z}$ analiziranimi prevodi. 


\section{Ucviljeni diktator}

Epizoda $\mathrm{v}$ izvirniku tematizira prihod ameriškega ambasadorja $\mathrm{v}$ izmišljeno državico v Latinski Ameriki s pomenljivim imenom San Guerreta, kar bi lahko prevedli kot Sveti Vojnica. Vodja (v izvirniku El Divino, Božanski, v prevodu ponekod poimenovan kar Ljubljeni vodja) Američana vozi na parade in oglede rezultatov razvoja državice, ki so rezultat ameriškega financiranja oblasti San Guerrete. Na eni strani je kritično predstavljena fasada režima, ki za prepričevanje ameriškega financerja gradi stanovanjska naselja iz kartona; na drugi strani pa ameriški ekonomski interesi, ki državo silijo v reforme "glede pokojnin, plač in drugih neslanosti«, kot se izrazi ameriški ambasador. To potrjuje tudi predgovor $\mathrm{k}$ ponovni italijanski izdaji epizode, $\mathrm{v}$ kateri Bunker takole kontekstualizira temo:

$\mathrm{V}$ tistem času je bila gonja proti komunizmu v svoji najintenzivnejši fazi. Američani so materialno podpirali katerokoli vlado, posebej v Latinski Ameriki, ki se je uradno zoperstavljala komunizmu, ne da bi natančneje preverjali, za kaj je bilo njihovo izdatno financiranje dejansko uporabljeno. O teh stvareh se je šepetalo, nikoli pa govorilo naglas, in zato je bil izlet na hipotetični otok San Guerreta, v državo, ki sta jo v veliki meri označevali diktatura in korupcija, priložnost, da se o tem prvič glasno spregovori skozi strip. (Secchi)

Prva dva analizirana odlomka prikazujeta pogovor med vodjem San Guerrete in ameriškim odposlancem na vožnji po mestu, kjer občudujeta "pridobitve« ameriškega financiranja, ter kasneje v predsednikovi pisarni.

Pogovor med ogledom mesta:

\begin{tabular}{|c|c|c|}
\hline & Prevod italijanskega izvirnika & Prevod hrvaškega prevoda \\
\hline $1 \mathrm{a}$ & $\begin{array}{l}\text { Vodja: Poglejte, gospod ambasador, } \\
\text { poglejte, kakšno razkošje, kajne? } \\
\text { Ker smo ves denar porabili za hiše, } \\
\text { nam ga za šole in bolnišnice ni nič } \\
\text { ostalo. }\end{array}$ & $\begin{array}{l}\text { Vodja: Poglejte, senor ambasador, } \\
\text { in se čudite! Vse, kar ste nam } \\
\text { poslali, smo porabili za gradnjo } \\
\text { teh veličastnih stavb! Za šole in } \\
\text { bolnišnice nimamo niti centa več! } \\
\text { Morali nam boste poslati tudi za to! } \\
\text { Američan: Oh! }\end{array}$ \\
\hline $1 b$ & $\begin{array}{l}\text { Američan: Da, da, ni slabo ... } \\
\text { Čestitam, dragi Božanski. Če } \\
\text { povem po pravici, sem se bal, da je } \\
\text { denar izginil. } \\
\text { Vodja: Res? Oh ... }\end{array}$ & $\begin{array}{l}\text { Američan: A ne pozabite na vojsko! } \\
\text { Nam je najpomembnejša močna } \\
\text { in dobro opremljena vojska, zaradi } \\
\text { tega vam tudi pošiljamo dolarje! } \\
\text { Vodja: Vsekakor, senor! }\end{array}$ \\
\hline
\end{tabular}


Situacija se ponovi v pisarni:

\begin{tabular}{|c|c|c|}
\hline & Prevod italijanskega izvirnika & Prevod hrvaškega prevoda \\
\hline $1 \mathrm{c}$ & $\begin{array}{l}\text { Američan: Samo trenutek. Obljubili } \\
\text { ste reforme. Doslej niste naredili } \\
\text { še ničesar. Želel bi videti vsaj } \\
\text { minimalne reforme. } \\
\text { Vodja: Reforme? Saj sem reformiral } \\
\text { tiste štiri peones } \\
\text { spo ki niso bili } \\
\text { sposobni za vojsko, to ni dovolj? } \\
\text { Američan: Govorim o socialnih } \\
\text { reformah, plačah, pokojninah in } \\
\text { podobnih neslanostih. } \\
\text { Vodja: A tako, seveda, počakajte, da } \\
\text { govorim s svojim ministrom. }\end{array}$ & $\begin{array}{l}\text { Američan: Dovolj mi je teh } \\
\text { zgradb in bolnišnic! Pa ja ne bomo } \\
\text { porabljali denarja za te neumnosti. } \\
\text { Raje oborožite vojsko! } \\
\text { Vodja: Dobro veste, da sem vrhovni } \\
\text { poveljnik svoje vojske. Vojska in } \\
\text { policija sta mi še kako pomembni! } \\
\text { Američan: V vsakem primeru } \\
\text { se moram posvetovati s svojimi } \\
\text { nadrejenimi! } \\
\text { Vodja: Upam, da boste objektivni v } \\
\text { prikazu tukajšnjega stanja! }\end{array}$ \\
\hline 1 č & $\begin{array}{l}\text { Vodja: Prekleti gringo, reforme } \\
\text { hočěs, kaj pa naj reformiram med } \\
\text { temi preklemanimi reveži. Morda } \\
\text { pa lahko najdem kakšno reformo na } \\
\text { hitro, samo toliko da ga prepričam, } \\
\text { da mi pošlje nove dolarje. }\end{array}$ & $\begin{array}{l}\text { Vodja: Prekleti gringo, ni podpisal. } \\
\text { Kaj pa misli: da je tisto, kar so že } \\
\text { dali, dovolj? Moj apetit je mnogo } \\
\text { večji in treba ga je potešiti. Ampak } \\
\text { kako naj ga prepričam? }\end{array}$ \\
\hline
\end{tabular}

Kot je razvidno iz primerjave izvirnika in prevoda, je v prevodu ideološka slika izvirnika precej spremenjena. Izvirni lik vodje San Guerrete je že v naslovu (Ucviljeni diktator, $v$ slov. Užaloščeni diktator) in tudi $\mathrm{v}$ besedilu večkrat eksplicitno označen z diktatorjem, državica pa prikazana kot ameriška kolonija. Vsi slabšalni, na socializem vezani izrazi v izvirniku (»socialnih reformah, plačah, pokojninah in podobnih neslanostih«; "preklemanimi reveži«; "stari razpadli umazani špekulant«; "smrdljivi plebejec«) so dosledno izbrisani in v celoti nadomeščeni z drugimi izvirnimi vsebinskimi motivi (1c, 1と̌) ali pa so ideološko nevtralizirani, kot v primeru v nadaljevanju (1k), ko »smrdljivi plebejec « $\mathrm{v}$ prevodu postane »bedni črv«.

V nadaljevanju, ko se diktator pogovarja s svojim podrejenim o tem, katero reformo bi se dalo najhitreje sprejeti, da se ugodi Američanu, pa je motiv reform zamenjan z motivom zahodnega dolga:

\footnotetext{
${ }^{8}$ Peones so mehiški kmetijski in fizični delavci, plačani po dnevnici.
} 


\begin{tabular}{|l|l|l|}
\hline & Prevod italijanskega izvirnika & Prevod hrvaškega prevoda \\
\hline 1d & $\begin{array}{l}\text { Podrejeni: Potrebovali bi eno } \\
\text { [reformo], ki ne stane veliko, npr. } \\
\text { vojne pokojnine ... } \\
\text { Vodja: Iz katere vojne? Tiste za } \\
\text { neodvisnost, prve ali druge svetovne? }\end{array}$ & $\begin{array}{l}\text { Podrejeni: Tu piše, da je neki gringo } \\
\text { vzel dve puški in zavoj municije in } \\
\text { ostal dolžen 28 dolarjev. } \\
\text { Vodja: Kdaj je bilo to? }\end{array}$ \\
\hline 1e & $\begin{array}{l}\text { Podrejeni: Tiste iz leta 1810, ki so jo } \\
\text { bojevali naši pogumni ... } \\
\text { Vodja: Aha, ni slabo, in koliko jih je } \\
\text { še živih s pravico do pokojnine? }\end{array}$ & $\begin{array}{l}\text { Podrejeni: Niti ne tako dolgo nazaj! } \\
\text { obresti ... } \\
\text { Vodja: Ne verjamem, da lahko na to } \\
\text { karto kaj dobimo ... }\end{array}$ \\
\hline 1f & $\begin{array}{l}\text { Podrejeni: Torej, aha, takole ... } \\
\text { Pred dvanajstimi leti so bili živi še } \\
\text { trije. A je eden umrl od lakote, drugi } \\
\text { pa od posta. } \\
\text { Vodja: In tretji? Še eden je ... }\end{array}$ & $\begin{array}{l}\text { Podrejeni: Še en dolg obstaja, } \\
\text { kvartopirski, iz leta 1912. } \\
\text { Vodja: Dovolj neumnosti. }\end{array}$ \\
\hline 1g & $\begin{array}{l}\text { Podrejeni: Tisti je pa še živ, } \\
\text { Božanski. } \\
\text { Vodja: Stari razpadajoči umazani } \\
\text { špekulant. No dobro, izvedimo to } \\
\text { reformo. Pripravi odpadni papir in } \\
\text { ga prinesi gor, da ga podpišem pred } \\
\text { gringovimi očmi. }\end{array}$ & $\begin{array}{l}\text { Podrejeni: Me še potrebujete, } \\
\text { sam se bom moral znajti, ti pa } \\
\text { medtem kaj napiši, da se te bodo } \\
\text { po tvoji smrti potomci vsaj po čem } \\
\text { spominjali! } \\
\text { prinesel odlok v podpis. } \\
\text { Američan: V redu, me veseli. }\end{array}$ \\
\hline 1h & $\begin{array}{l}\text { Vodja: Smo že uredili. Najprej } \\
\text { komo reformirali pokojnine. V }\end{array}$ & $\begin{array}{l}\text { Vodja: Dragi ambasador, veseli } \\
\text { me, da vas lahko seznanim z našimi } \\
\text { načrti glede moje hrabre vojske in } \\
\text { manevrov, ki niso bili poceni ... } \\
\text { Američan: To me že bolj zanima ... }\end{array}$ \\
\hline
\end{tabular}

Vse omembe nujnosti reform (1c-1f), s katerimi preti ameriški predstavnik, so $\mathrm{v}$ prevodu zamenjane $\mathrm{z}$ referencami na vojsko in deloma policijo (»A ne pozabite na vojsko! Nam je najpomembnejša močna in dobro opremljena vojska, zaradi tega vam tudi pošiljamo dolarje!«; "Dovolj mi je teh zgradb in bolnišnic! Pa ja ne bomo porabljali denarja za te neumnosti. Raje oborožite vojsko!«; »Dobro veste, da sem vrhovni poveljnik svoje vojske. Vojska in policija sta mi še kako pomembni!«) in z motivom tujega dolga (»Tu piše, da je neki gringo vzel dve puški in zavoj municije in ostal dolžen 28 dolarjev.«, "Še en dolg obstaja, kvartopirski, iz leta 1912.")

Za analizo je zanimiv še eden od končnih prizorov, ko odkrijejo, da se je Alan infiltriral v predsednikovo palačo, ta pa se pred preganjalci 
skuša zateči ravno v pisarno, v kateri je ameriški odposlanec, saj meni, da mu bo kot ameriškemu državljanu nudil zaščito:

\begin{tabular}{|l|l|l|}
\hline & Prevod italijanskega izvirnika & Prevod hrvaškega prevoda \\
\hline $1 \mathrm{i}$ & $\begin{array}{l}\text { Alan Ford: Moram se pogovoriti s } \\
\text { predstavnikom svoje države ... } \\
\text { - Stoj! }\end{array}$ & $\begin{array}{l}\text { Alan Ford: Poskušal bom pobegniti } \\
\text { od tod, pa naj bo, kar bo ... } \\
\text { - Ne! Ne tja! }\end{array}$ \\
\hline $1 \mathrm{j}$ & $\begin{array}{l}\text { Stoj! Stoj! } \\
\text { - Na pomoč! Atentat! } \\
\text { Alan Ford: Sveta nebesa! }\end{array}$ & $\begin{array}{l}\text { Stoj! Stoj! } \\
\text { - Na pomoč, atentator! } \\
\text { Alan Ford: Ojoj! Konec je z mano! }\end{array}$ \\
\hline $1 \mathrm{k}$ & $\begin{array}{l}\text { Vodja: Kdo je ta smrdljivi plebejec, } \\
\text { ki si drzne zmotiti naša posvetovanja } \\
\text { na visoki ravni? } \\
\text { Alan Ford: Jaz sem Američan! }\end{array}$ & $\begin{array}{l}\text { Vodja: Kdo je ta bedni črv, ki si } \\
\text { drzne prekinjati naše pogovore na } \\
\text { najvišji ravni? } \\
\text { Alan Ford: Jaz sem Alan Ford! }\end{array}$ \\
\hline 11 & $\begin{array}{l}\text { Alan Ford: Poslušajte, preslepiti vas } \\
\text { hočejo, hiše so iz kartona, pokojnina } \\
\text { je samo ena, in še ta iz neke davne } \\
\text { vojne ... } \\
\text { Američan: Kaj pa govori? }\end{array}$ & $\begin{array}{l}\text { Alan Ford: Poslušajte, slepijo vas! } \\
\text { Tiste stavbe so iz papirja, bolnišnic } \\
\text { in šol ni, Božanski si ves denar tlači } \\
\text { v lasten žep! } \\
\text { Američan: Kaj? Kaj? }\end{array}$ \\
\hline
\end{tabular}

Iz prevoda so izbrisane tudi vse reference na ZDA: »Moram se pogovoriti s predstavnikom svoje države ... « je v prevodu nevtraliziran v »Poskušal bom pobegniti od tod, pa naj bo, kar bo.«, "Jaz sem Američan!" pa je v prevodu spretno spremenjen kar v »Jaz sem Alan Ford!«.

\section{(Ne) glasajte za Notaxa}

Epizoda v izvirniku tematizira politično volilno kampanjo politika, ki ljudstvu obljublja gradove $\mathrm{v}$ oblakih, $\mathrm{v}$ resnici pa zastopa zgolj interese kapitalske elite. Prevod je analiziran na treh tematskih mestih: med javnim nastopom kandidata Notaxa na volilnem zboru in kongresu milijonarjev, $v$ zasebnih pogovorih s člani svojega volilnega štaba ter $\mathrm{v}$ pogovorih $\mathrm{z}$ inteligenco (pogovor $\mathrm{s}$ slikarjem ob odprtju razstave $\mathrm{v}$ okviru volilne kampanje).

Prvi analizirani prizor prikazuje kandidata Notaxa na javnem volilnem shodu: 


\begin{tabular}{|c|c|c|}
\hline & Prevod italijanskega izvirnika & Prevod hrvaškega prevoda \\
\hline $2 \mathrm{a}$ & $\begin{array}{l}\text { Delavci komaj čakajo vaš govor, } \\
\text { bodoči guverner. } \\
\text { Notax: Tudi jaz komaj čakam, da ga } \\
\text { povem, a ne hitimo, izpade slabo, se } \\
\text { je zbralo kaj ljudi? }\end{array}$ & $\begin{array}{l}\text { Narod komaj čaka, da sliši vaše } \\
\text { besede, bodoči dikta... pardon, } \\
\text { guverner! } \\
\text { Notax: Tudi jaz, želim si le, da se } \\
\text { s svojimi volilci, ki bodo gotovo } \\
\text { glasovali zame, objamem, ali pa jih } \\
\text { bom ... Oh, kje pa so? }\end{array}$ \\
\hline $2 b$ & $\begin{array}{l}\text { Notax: Bratje delavci, prijatelji, } \\
\text { preden začnem s svojo propagandno } \\
\text { turnejo, sem želel priti k vam, ki ste } \\
\text { najbolj živ stik z ljudstvom in velika } \\
\text { potencialna masa volilcev. }\end{array}$ & $\begin{array}{l}\text { Notax: Najprej vam obljubljam, da } \\
\text { bomo naše sovražnike vse spravili v } \\
\text { mišje luknje. To je naša zemlja in } \\
\text { kdor ne misli tako, ga bomo ... }\end{array}$ \\
\hline $2 c$ & $\begin{array}{l}\text { Alan Ford: Uf, ti govori se pa res } \\
\text { nikoli ne spreminjajo, na pamet jih } \\
\text { znam. }\end{array}$ & $\begin{array}{l}\text { Alan Ford: Uh, kako je tip } \\
\text { dolgočasen. Najbrž je član kakega } \\
\text { Ku Kluks Klana, da govori take } \\
\text { neumnosti! }\end{array}$ \\
\hline $2 \mathrm{c}$ & $\begin{array}{l}\text { Notax: Za državo, ki bo bolj } \\
\text { moderna, bolj učinkovita, bolj } \\
\text { ustrezajoča potrebam skupnosti, } \\
\text { zato, da ljudstvo približamo } \\
\text { vodjem in sodelujemo v političnem } \\
\text { življenju. } \\
\text { Alan Ford: Eh, tudi ognjemet } \\
\text { imajo, na vse mislijo, da bi naredili } \\
\text { spektakel. }\end{array}$ & $\begin{array}{l}\text { Notax: In zato, dragi prijatelji, } \\
\text { volite zame, in jaz vam bom } \\
\text { zagotovil avto in jahto in vilo in } \\
\text { bazen in vse, kar hočete, samo } \\
\text { volite zame! } \\
\text { Alan Ford: Hm, celo strokovnjake } \\
\text { za ognjemet so pripeljali, da } \\
\text { poveličujejo ta ušivi miting! }\end{array}$ \\
\hline $2 \mathrm{~d}$ & $\begin{array}{l}\text { Notax: Izvedli bomo davčno } \\
\text { reformo, ki bo močno zmanjšala } \\
\text { davke delavcem in izpustila tiste, } \\
\text { ki zaslužijo malo, in jih celo malce } \\
\text { subvencionirali, ampak ... zmogli } \\
\text { bomo! }\end{array}$ & $\begin{array}{l}\text { Notax: ... da bom skrbel samo za } \\
\text { vas, za vas in za nikogar drugega, da } \\
\text { bom naredil vse, da bi v vaših hišah } \\
\text { tekla med in mleko in da bom za } \\
\text { vas osvojil ves svet! }\end{array}$ \\
\hline
\end{tabular}

V prevodu je socialna demagogija iz izvirnika zamenjana z nacionalnim populizmom, kar se kaže v doslednem zamenjevanju levo konotiranega izrazja z desnim, delavci tako postanejo narod. Nacionalistični element kot prevodni ekvivalent socialni demagogiji je v prevodu izrazito poudarjen, tudi z npr. konkretnimi izvirnimi referencami na Ku Kluks Klan (»Najprej vam obljubljam, da bomo naše sovražnike vse spravili v mišje luknje. To je naša zemlja, in kdor ne misli tako, ga bomo ... «; »Uh, kako je tip dolgočasen. Najbrž je član kakega Ku Kluks Klana, da govori take neumnosti!«). Motivi učinkovitosti države, težnje po 
politični participaciji in pravičnejših davčnih reformah pa so nadomeščene $s$ kapitalistično grabežljivostjo ter predvolilnim leporečenjem in zaklinjanjem (»In zato, dragi prijatelji, volite zame, in jaz vam bom zagotovil avto in jahto in vilo in bazen in vse, kar hočete, samo volite zame!«; "... da bom skrbel samo za vas, za vas in za nikogar drugega, da bom naredil vse, da bi v vaših hišah tekla med in mleko in da bom za vas osvojil ves svet! «).

Naslednji analizirani prizor prikazuje Notaxa na »kongresu milijonarjev«, kjer je njegova retorika povsem drugačna:

\begin{tabular}{|l|l|l|}
\hline & Prevod italijanskega izvirnika & Prevod hrvaškega prevoda \\
\hline 2e & $\begin{array}{l}\text { Voznik: Na kongres milijonarjev? } \\
\text { Notax: Ja, in hitro! Uf, še dobro, da } \\
\text { ni bilo atentata, in kako smrdi tam } \\
\text { notri, bencin in druge svinjarije, } \\
\text { nafta in podobno ... Ah, kaj vse } \\
\text { mora pretrpeti politični človek med } \\
\text { razcapanci in reveži. Bog, kako } \\
\text { sovražim rajo. }\end{array}$ & $\begin{array}{l}\text { Notax: Ja, hitro. Na srečo ni bilo } \\
\text { smrdela po olju in bencinu! Politik } \\
\text { mora dosti pretrpeti na poti do } \\
\text { guvernerske palače, in tega mu nihče } \\
\text { ne prizna! }\end{array}$ \\
\hline
\end{tabular}

In kasneje, iz nagovora na kongresu milijonarjev:

\begin{tabular}{|l|l|l|}
\hline & Prevod italijanskega izvirnika & Prevod hrvaškega prevoda \\
\hline 2f & $\begin{array}{l}\text { Notax: In če mi boste dali glas, } \\
\text { bomo izvedli posebno reformo: bolj } \\
\text { bodo ljudje bogati, manj jih bomo } \\
\text { obdavčili, najbogateǰ̌i pa bodo } \\
\text { sploh davkov oproščeni. Namesto } \\
\text { tega pa bomo obdavčili proletariat: } \\
\text { manj bodo zaslužili, bolj jih bomo } \\
\text { davčili. }\end{array}$ & $\begin{array}{l}\text { Notax: In če boste volili zame, vam } \\
\text { obljubljam, da bom razveljavil vse } \\
\text { zakone, po katerih morajo bogataši } \\
\text { plačevati davke! Omogočil vam bom } \\
\text { še večje dobičke, še večje zaslužke, } \\
\text { še boljše možnosti, da svobodno } \\
\text { poslujete! }\end{array}$ \\
\hline 2g & $\begin{array}{l}\text { Dobro, bravo, tako se dela! } \\
\text { Notax: Hvala, gospodje, hvala, } \\
\text { hvala, to seveda sprejmem kot } \\
\text { simbolnen prispevek, nakazila, ehm } \\
\text { ‥ na ta še počakam ... }\end{array}$ & $\begin{array}{l}\text { Tako je! Tako se govori! Bravo! } \\
\text { Notax: Razumljivo, da moja volilna } \\
\text { kampanja terja določene stroške in } \\
\text { zaradi tega je vsak prispevek ... oh, } \\
\text { da ... kako ste ljubeznivi! }\end{array}$ \\
\hline
\end{tabular}

Do podobnih sprememb kot zgoraj v prevodu prihaja tudi na drugem analiziranem mestu: $v$ zasebnem pogovoru Notax prizna, kako na živce mu gre "raja" (v izv. "popolaccio«, pejorativna izpeljanka iz "popolo" za ljudstvo), v prevodu pa je ta izjava nadomeščena s splošnejšo o tem, 
kako težko je delo politika pri njegovem vzponu na vrh. V prevodu je, kot $\mathrm{v}$ prejšnjem primeru, znova izpuščen proletariat ("namesto tega pa bomo obdavčili proletariat: manj bodo zaslužili, bolj jih bomo davčili«) in zamenjan z davčnimi odpustki za bogate in izvirnim motivom zakonske razveljavitve kapitalu nenaklonjenih zakonov in neoliberalno obljubo svobodnega poslovanja (»In če boste volili zame, vam obljubljam, da bom razveljavil vse zakone, po katerih morajo bogataši plačevati davke! Omogočil vam bom še večje dobičke, še večje zaslužke, še boljše možnosti, da svobodno poslujete!«). To kaže, da prevod tudi na tem mestu svobodno prehaja v priredbo.

Za analizo je zanimiv še eden od končnih prizorov, $v$ katerem Notax obišče umetniško razstavo, postavljeno $\mathrm{v}$ okviru volilne kampanje; $\mathrm{v}$ prizoru je tematiziran odnos med politiko, oblastjo in umetnostjo.

\begin{tabular}{|c|c|c|}
\hline & Prevod italijanskega izvirnika & Prevod hrvaškega prevoda \\
\hline $2 \mathrm{~h}$ & $\begin{array}{l}\text { Novinar: Je to umetniška razstava? } \\
\text { Umetnik: Zakaj? Se ne vidi? }\end{array}$ & $\begin{array}{l}\text { Novinar: Je to ta umetniška } \\
\text { razstava? } \\
\text { Umetnik: Zakaj sprašujete? Ali ne } \\
\text { vidite? }\end{array}$ \\
\hline $2 \mathrm{i}$ & $\begin{array}{l}\text { Novinar: Ste slišali, kolegi novinarji, } \\
\text { to naj bi bila umetniška razstava, } \\
\text { povezana z Notaxovo volilno } \\
\text { kampanjo! } \\
\text { Novinar } 2 \text { : Ah, vsekakor, trpljenje } \\
\text { teh kamnov in sporočilo bodeče žice } \\
\text { so pristno delo intelekta. }\end{array}$ & $\begin{array}{l}\text { Novinar: Ste videli, kolegi novinarji? } \\
\text { To je umetniška razstava, posvečena } \\
\text { Notaxovi volilni kampanji! } \\
\text { Novinar 2: Zares čudovito, } \\
\text { vznemirljivo, plemenito! Ni jasno, } \\
\text { kaj predstavlja ... ampak, ali je to } \\
\text { pomembno? }\end{array}$ \\
\hline $2 j$ & $\begin{array}{l}\text { Umetnik: Propadli in kapriciozni } \\
\text { pisunčki, nesposobni in butasti } \\
\text { megalomani, kdo vam je dal } \\
\text { pravico, da sodite o umetnosti? In } \\
\text { da z brutalno vulgarnostjo blatite } \\
\text { tistega, ki svoja dela razstavlja s } \\
\text { predanostjo in potrpljenjem? }\end{array}$ & $\begin{array}{l}\text { Umetnik: Idioti! Bedaki! Kreteni! } \\
\text { Krokodili! Papagaji! Nosorogi! } \\
\text { Šakali! Smrdljivi dihurji! Kako bi vi } \\
\text { lahko razumeli umetniško dušo, ko } \\
\text { pa vas zanimata samo boks in ragbi, } \\
\text { o umetnosti pa pojma nimate! }\end{array}$ \\
\hline $2 \mathrm{k}$ & $\begin{array}{l}\text { Novinar: Oh ti razcapani bednik, } \\
\text { umetnik, če ti uspe naivcem } \\
\text { prodajati zalepljene skale, ovite z } \\
\text { bodečo žico, pa daj, toliko bolje } \\
\text { zate, a ne izzivaj, ker te bom, če ne } \\
\text { nehaš, celega obril ... } \\
\text { Umetnik: Poskusi, če si upaš! }\end{array}$ & $\begin{array}{l}\text { Misliš, da se je primerno tako } \\
\text { pogovarjati s tiskom? Ko te zgrabim, } \\
\text { ti bom ostrigel vse te tvoje dlake in } \\
\text { poganjke! Naučil te bom, kako se } \\
\text { obnaša! } \\
\text { - Samo drzni si, trobilo! }\end{array}$ \\
\hline
\end{tabular}




\begin{tabular}{|c|c|c|}
\hline 21 & $\begin{array}{l}\text { Voila, monsieur, stranki sem } \\
\text { obdelal brado in brke. } \\
\text { Umetnik: Hudimana, ta pa si res } \\
\text { upa! }\end{array}$ & $\begin{array}{l}\text { Kar si hotel, to si dobil! In to } \\
\text { brezplačno! } \\
\text { Umetnik: Vraga, ta res naredi, kar } \\
\text { reče! }\end{array}$ \\
\hline $2 \mathrm{~m}$ & $\begin{array}{l}\text { Umetnik: O bog, kakšna groza, } \\
\text { kakšna kazen, kakšno uboštvo ... } \\
\text { - Povsem v skladu s tvojimi deli, } \\
\text { umetniček, raje se loti konj in } \\
\text { žensk, če hočeš kaj zaslužiti! }\end{array}$ & $\begin{array}{l}\text { Umetnik: O bog, kako izgledam! } \\
\text { Kakšna grozota! } \\
\text { - Tako kot tvoji kipi! Raje se loti } \\
\text { konjev ali galebov, tako blago boš } \\
\text { lažje prodajal! }\end{array}$ \\
\hline $2 n$ & $\begin{array}{l}\text { Notax: Je to umetniška razstava? } \\
\text { - Tako so nam rekli ... }\end{array}$ & $\begin{array}{l}\text { Notax: Je to ta umetniška razstava? } \\
\text { - Tako so nam rekli! }\end{array}$ \\
\hline 20 & $\begin{array}{l}\text { Notax: No, saj veste, to je neo- } \\
\text { nouvelle-new-neue vague val, treba } \\
\text { se je poglobiti in izkazati zanimanje! }\end{array}$ & $\begin{array}{l}\text { Notax: Kot izkušen politik vam } \\
\text { pravim, da so to čudovita dela, } \\
\text { vredna pozornosti in občudovanja! }\end{array}$ \\
\hline $2 p$ & $\begin{array}{l}\text { Notax: Ah, lepo, lepo, gre za } \\
\text { določeno moč izraza, ki izhaja iz } \\
\text { dela, nekakšno vitalnost, intelekt, } \\
\text { kje je umetnik, da mu izrečem } \\
\text { pohvalo, jaz sem vedno z mladimi } \\
\text { in za mlade ... }\end{array}$ & $\begin{array}{l}\text { Notax: To je vse prekrasno, polno } \\
\text { duha in občutja, nekaj, kar poglablja } \\
\text { našo dušo! Srečen bi bil, ko bi imel } \\
\text { čast seči v roko našemu umetniku! }\end{array}$ \\
\hline $2 \mathrm{r}$ & $\begin{array}{l}\text { Umetnik: Samo trenutek, da se } \\
\text { oblečem ... takoj bom ... ehm ... }\end{array}$ & $\begin{array}{l}\text { Umetnik: Samo hipec, samo hipec, } \\
\text { da se oblečem ... hm ... prihajam! }\end{array}$ \\
\hline $2 \mathrm{~s}$ & $\begin{array}{l}\text { Umetnik: Vam je všeč, visokost, } \\
\text { kako sem v kamnu izrazil grozo in } \\
\text { katastrofe vojne; kamen predstavlja } \\
\text { človeka, ki izhaja iz zemlje, oziroma } \\
\text { iz kamna, bodeča žica pa vojno in } \\
\text { njene grozote! }\end{array}$ & $\begin{array}{l}\text { Umetnik: Veseli me, da vam je všeč! } \\
\text { Vi ste eden redkih, ki je razumel } \\
\text { mojo misel, pa me zato radosti, da } \\
\text { bodo moja dela s svojo globino in } \\
\text { iskrenim sporočilom povedla volilce } \\
\text { na glasovanje, da tam izvršijo svojo } \\
\text { domoljubno dolžnost! }\end{array}$ \\
\hline $2 \check{s}$ & $\begin{array}{l}\text { Notax: Seveda, seveda, jaz sem za } \\
\text { umetnost in za umetnike, ki so za } \\
\text { vas in z vami! Rad bi se dotaknil } \\
\text { tega čudovitega primerka nove } \\
\text { kiparske umetnosti, ki ... }\end{array}$ & $\begin{array}{l}\text { Notax: Vsekakor, vsekakor! Jaz sem } \\
\text { za umetnost in z umetnostjo. To bi } \\
\text { želel dokazati tako, da se s kazalcem } \\
\text { dotaknem genialnega dela svojega } \\
\text { somišljenika! Naj bo to znak ... }\end{array}$ \\
\hline
\end{tabular}

Primerjava izvirnika in prevoda pokaže, da so vse reference na umetnost $\mathrm{v}$ prevodu poenostavljene $(2 \mathrm{j}, 2 \mathrm{k}, 2 \mathrm{o}, 2 \mathrm{p})$; to je še posebej vidno $\mathrm{v} 2 \mathrm{j}$, kjer umetnik v prevodu posredno kritizira zahodno potrošniško kulturo, ko obiskovalce zmerja s tem, da umetnosti ne razumejo, ker jih zanimata "samo šport in ragbi«; hkrati je zamenjava kompleksnejše kritike (»Propadli in kapriciozni pisunčki, nesposobni in butasti megalomani, 
kdo vam je dal pravico, da sodite o umetnosti?«) z značilnim nizanjem enostavnih zmerljivk (»Idioti! Bedaki! Kreteni! Krokodili! Papagaji! Nosorogi! Šakali! Smrdljivi dihurji!«) zelo alanfordovska, prav tisto mesto avtentičnosti Brixyjevega prevoda, zaradi katere je tako popularen.

Umetnost in lik umetnika sta v prevodu do neke mere trivializirana: razni žargonski (tudi sprenevedavi) izrazi ("pristno delo intelekta«; »neo-nouvelle-new-neue vague val«; »moč izraza, ki izhaja iz dela«; "vitalnost, intelekt«) so v prevodu zamenjani s prozaično politično hvalo umetnosti in umetnikom (»čudovita dela, vredna pozornosti in občudovanja«; "prekrasno, polno duha in občutja, nekaj, kar poglablja našo dušo«). Zanimiva je tudi zamenjava žensk z galebi v $2 \mathrm{~m}$ (»Raje se loti konjev ali galebov, tako blago boš lažje prodajal!«), ki bi jo lahko razumeli kot cenzuro seksistične reference.

Spremenjen je tudi lik umetnika: v prevodu je ta nekoliko pohlevnejši, s poenostavljeno govorico, svoje delovanje pa razume zelo instrumentalno kot volilno spodbudo državljanom in dejanje patriotizma (»Veseli me, da vam je všeč! Vi ste eden redkih, ki je razumel mojo misel, pa me zato radosti, da bodo moja dela s svojo globino in iskrenim sporočilom povedla volivce na glasovanje, da tam izvršijo svojo domoljubno dolžnost! «), kar je v izvirniku povsem odsotno, četudi je tudi tam umetnik predstavljen kot podrejen politični oblasti $(2 \mathrm{p}, 2 \mathrm{r})$.

Osrednji lik Notaxa in celoten dogajalni kontekst sta v prevodu premaknjena na polje desnega populizma: na to $\mathrm{v}$ prevodu kažeta tudi poudarjen opis umetnosti in umetnikov kot nekritičnih slug ideologije ter dejstvo, da je v prevod vnesen izviren motiv moči medijske manipulacije (2k).

\section{Formule}

Kot navajam že v prvem delu članka, ta epizoda ni bila prevedena po izhodiščnem številčenju izvirnikov, pač pa izpuščena in prevedena šele leta 1990, pri Vjesniku, v trojni številki.

Epizoda najverjetneje tematizira sovjetski realsocializem, posebej v navezavi na dogodke na Čehoslovaškem v drugi polovici 60. let ter na hladno vojno in nevarnost nuklearnih napadov. V epizodi Profesor Alana pošlje na tajno misijo $\mathrm{v}$ neko tovarno, kjer naj bi se dogajale nepravilnosti v zvezi $s$ »strateško izmenjavo tehnično-kulturnih« nevarnih snovi s »sovražnimi državami«; v ozadju je nevarnost jedrske vojne. Ko Alan pride v tovarno, na obisk prispe delegacija »Bruskijev« (bru$s c o=$ ita. grobo, rezko, nerafinirano). Vodja delegacije je avtoritaren 
"proletarec«, ki Alana kasneje ugrabi in po scenariju, ki spominja na stalinistične metode, preizpraša njegove morebitne »kontrarevolucionarne« težnje.

Potencialne kontroverznosti epizode sta se zavedala tudi Magnus in Bunker; Bunker jo v predgovoru (v ponatisu izvirnika leta 2014) povzema takole:

Te številke se še posebej dobro spominjam, ker sva se z Magnusom zaradi nje kake dobre pol ure tako smejala, da naju je pošteno bolel trebuh. Zakaj? Predvsem zato, ker to, kar danes imenujemo 'politična satira', januarja 1970 še ni obstajalo. Obstajali so razni 'nedotakljivi', ki se jih ni smelo dotikati (sicer bi ne bili nedotakljivi), in eden od njih je bila italijanska komunistična partija, s kratico PCI (Partito Comunista Italiano). Socialistična Evropa je doživljala pretrese, na Čehoslovaškem je prihajalo do vrenja. Na levem političnem polu je prihajalo do razprav in različnih pogledov in epizoda Formule, ki smeši sovjetsko ortodoksijo, je sprožila nekaj vznemirjenja ter različnih odzivov glede 'nazorov' stripa Alan Ford.

Prevod te epizode do te mere zvesto sledi izvirniku, da primerjavo med izvirnikom in prevodom navajam samo tam, kjer dejansko prihaja do relevantnih vsebinskih odklonov, sicer pa prevajam po italijanskem izvirniku.

\begin{tabular}{|l|l|l|}
\hline & Prevod italijanskega izvirnika & Prevod hrvaškega prevoda \\
\hline 3a & $\begin{array}{l}\text { Dobrodošli v našo tovarno. Gospod Brott vas pričakuje. } \\
\text { Funkcionar: Umakni se mi, ker smrdiš po gnilem zelju. }\end{array}$ \\
\hline 3b & $\begin{array}{l}\text { Funkcionar: Pojdi mi s poti, produkt kapitalizma. Mimo gredo } \\
\text { proletarci. } \\
\text { - Eh? }\end{array}$ \\
\hline 3c & $\begin{array}{l}\text { Hvala, hvala, ker ste prišli. Sedaj vam bom pokazal nove gosenice, ki jih } \\
\text { ravno preizkušamo. } \\
\text { Funkcionar: Kar počasi ... }\end{array}$ \\
\hline 3č & $\begin{array}{l}\text { Glejte, že šeststotriinšestdeset ur } \\
\text { so v obratovanju, pa se ni zrahljal } \\
\text { niti vijak. } \\
\text { Funkcionar: Aha, torej še vedno } \\
\text { uporabljate te zastarele tehnike. } \\
\text { Kadar želimo mi preizkusiti } \\
\text { delovanje gosenic, jih pošljemo v } \\
\text { Cenoslovatijo, haha! }\end{array}$ & $\begin{array}{l}\text { Glejte, delajo že sedemsto } \\
\text { šestintrideset ur, pa se ni zrahljal niti } \\
\text { vijak! } \\
\text { ta problem? Ko moramo mi ste uspeli rešiti } \\
\text { preizkušati gosenice, jih pošljemo } \\
\text { našim prijateljskim sosedam, haha! }\end{array}$ \\
\hline 3d & $\begin{array}{l}\text { Funkcionar: Najbrž se sprašujete, zakaj sem ukazal, naj vas pripeljejo sem. } \\
\text { Alan Ford: Ne, nisem radovedne sorte. }\end{array}$ \\
\hline
\end{tabular}




\begin{tabular}{|c|c|c|}
\hline $3 e$ & \multicolumn{2}{|c|}{$\begin{array}{l}\text { Funkcionar: Kako ne? To je del osnovnega odgovora v takih primerih! } \\
\text { Alan Ford: A tako? In kaj bi moral reči? }\end{array}$} \\
\hline $3 \mathrm{f}$ & \multicolumn{2}{|c|}{$\begin{array}{l}\text { Funkcionar: Reči bi moral »Zakaj ste me pripeljali sem?» } \\
\text { Alan Ford: Aha, torej: "Zakaj ste me pripeljali sem?» }\end{array}$} \\
\hline $3 g$ & \multicolumn{2}{|c|}{$\begin{array}{l}\text { Funkcionar: Ne, sedaj ne morem potešiti vaše radovednosti, vse dokler } \\
\text {... } \\
\text { Alan Ford: No, nič hudega, saj me tako ni zanimalo. }\end{array}$} \\
\hline $3 \mathrm{~h}$ & \multicolumn{2}{|c|}{$\begin{array}{l}\text { Funkcionar: Ampak moraš vztrajati, razumeš, vztrajaj! } \\
\text { Alan Ford: Vztrajam! }\end{array}$} \\
\hline $3 \mathrm{i}$ & \multicolumn{2}{|c|}{$\begin{array}{l}\text { Funkcionar: Torej, vemo, da v podjetju zasedaš odgovoren položaj, a } \\
\text { imaš nizko plačo in pogosto razmišljaš o prihodnosti, kajne? } \\
\text { Alan Ford: Pa še kako, sedaj moram plačevati še } 10 \% \text { več in ne vem, kje } \\
\text { naj jih najdem. }\end{array}$} \\
\hline $3 \mathrm{j}$ & \multicolumn{2}{|c|}{$\begin{array}{l}\text { Funkcionar: Tvojih skrbi je konec. Dobil si priložnost, da zaslužiš toliko } \\
\text { denarja, kolikor hočeš. Sedaj pa srkniva kapljico belega. } \\
\text { Alan Ford: Kolikor hočem? Tudi de... deset dolarjev? }\end{array}$} \\
\hline $3 \mathrm{k}$ & $\begin{array}{l}\text { Funkcionar: Poglej, čisti } \\
\text { šampanjec, iz Italije, kliče se } \\
\text { Perrazzoni in je prestižen izdelek, } \\
\text { narejen iz odpadne pločevine. } \\
\text { Alan Ford: To bo pa najbrž prava } \\
\text { dobrota. }\end{array}$ & $\begin{array}{l}\text { Glej, originalni šampanjec, } \\
\text { zagarantirano! Prihaja iz znane } \\
\text { države izvoznice in se imenuje } \\
\text { Žumberačka vodica. Čez zamašek } \\
\text { ima celo staniol. } \\
\text { - Gotovo je izvrstna. }\end{array}$ \\
\hline 31 & \multicolumn{2}{|l|}{$\begin{array}{l}\text { Funkcionar: Sedaj bo počilo. } \\
\text { Alan Ford: Ni počilo. }\end{array}$} \\
\hline $3 \mathrm{~m}$ & $\begin{array}{l}\text { Funkcionar: Ah ja, to je posebna } \\
\text { vrsta za superfine, ta ne poči. } \\
\text { Alan Ford: Dobro, potem pa } \\
\text { natočimo. }\end{array}$ & $\begin{array}{l}\text { Aha, to je posebna vrsta za } \\
\text { superprefinjene. Brez poka! } \\
\text { - Kakšna skrb za človeka! }\end{array}$ \\
\hline $3 n$ & \multicolumn{2}{|l|}{$\begin{array}{l}\text { Alan Ford: In kje je šampanjec? } \\
\text { Funkcionar: Torej ... ne razumem ... }\end{array}$} \\
\hline 30 & \multicolumn{2}{|c|}{$\begin{array}{l}\text { Funkcionar: Prekleti šampanjec, pridi ven, pridi že ven! } \\
\text { Alan Ford: Poskusite s tanki. Najbrž je to nek kontrarevolucionaren } \\
\text { šampanjec. }\end{array}$} \\
\hline $3 \mathrm{p}$ & \multicolumn{2}{|c|}{$\begin{array}{l}\text { Funkcionar: Kaj? Poba, to mi res smrdi po kontrarevolucionarnem duhu. } \\
\text { Alan Ford: Ne, kje pa, jaz sem kontrakontrarevolucionar. }\end{array}$} \\
\hline $3 r$ & \multicolumn{2}{|c|}{ Funkcionar: Kontrakontrarevolucionar. Ena, dva, $\operatorname{tri}^{10}$, ah, ja ... } \\
\hline
\end{tabular}

${ }^{9}$ Zaradi paralelne proletarske ekonomije, ki vlada v tovarni, po kateri morajo novoprispeli starejšim delavcem dajati del plače.

${ }_{10}$ Šteje na prste. 


\begin{tabular}{|c|c|c|}
\hline $3 \mathrm{~s}$ & $\begin{array}{l}\text { Funkcionar: Da, da, brat, popijva ta } \\
\text { Alan Ford: To bi bile moje sanje. }\end{array}$ & impanjec. \\
\hline $3 \check{s}$ & $\begin{array}{l}\text { Funkcionar: Aha, glej ga, sočni sok } \\
\text { tega svetlega nektarja. } \\
\text { Alan Ford: A, to je torej } \\
\text { šampanjec, mi mu rečemo granita. }\end{array}$ & $\begin{array}{l}\text { Aha, glej, to je koncentrat tega } \\
\text { svetlega nektarja! } \\
\text { - A, to je torej šampanjec, pri nas } \\
\text { mu rečemo pesek. }{ }^{11}\end{array}$ \\
\hline $3 \mathrm{t}$ & $\begin{array}{l}\text { Funkcionar: Ti si krasen fant, ki ga } \\
\text { izkorišča plenilski kapitalistično- } \\
\text { imperialistični sistem, kajne? } \\
\text { Alan Ford: Hm, ja, nekaj takega, } \\
\text { čeprav ošpic pa še nisem imel. }\end{array}$ & $\begin{array}{l}\text { - Ti si najobičajnejši produkt } \\
\text { kapitalistično-imperialistično- } \\
\text { razbojniškega sistema, kajne? }\end{array}$ \\
\hline $3 \mathrm{u}$ & \multicolumn{2}{|c|}{$\begin{array}{l}\text { Funkcionar: Poslušaj me, ti debil. Jaz sicer potrebujem ravno enega } \\
\text { takega, ampak ti pa že pretiravaš. Znaš igrati šah? } \\
\text { Alan Ford: Šah? Ja, delal sem dopisni tečaj, a ga nisem uspel dokončati, ker } \\
\text { sem začasno ostal brez tistega, čemur vi rečete nizkotna materialna sredstva. }\end{array}$} \\
\hline $3 \mathrm{v}$ & \multicolumn{2}{|c|}{$\begin{array}{l}\text { Funkcionar: Imamo čas, dokler ne pride moj tova... moj prijatelj. Igrajva } \\
\text { torej. } \\
\text { Alan Ford: Jaz z belimi in ti s črnimi, v redu? }\end{array}$} \\
\hline
\end{tabular}

In ko začne avtokrat proti Alanu v šahovskem dvoboju izgubljati:

\begin{tabular}{|l|l|l|}
\hline & Prevod italijanskega izvirnika & Prevod hrvaškega prevoda \\
\hline $3 z$ & $\begin{array}{l}\text { Funkcionar: Prekleto, to je podlo } \\
\text { delo kontrarevolucionarjev, ki so se } \\
\text { prodali imperializmu. }\end{array}$ & $\begin{array}{l}\text { Prekleto, to je najobičajnejša } \\
\text { nenačelna zarota pokvarjenega } \\
\text { imperializma! }\end{array}$ \\
\hline $3 z ̌$ & $\begin{array}{l}\text { Funkcionar: Ko ne moremo ničesar doseči z racionalnim in metodičnim } \\
\text { razmislekom, smo prisiljeni uporabiti edino metodo, ki nam še preostane } \\
\text { za uničenje kontrarevolucionarjev. }\end{array}$ \\
\hline $3 a a$ & $\begin{array}{l}\text { Funkcionar: Torej, izdajalec načel bratstva, pogubljeni kontrarevolucionar! } \\
\text { Boš spontano in demokratično izrekel samokritiko ali ne? } \\
\text { Alan Ford: Kaj pa moram samokritizirati? }\end{array}$ \\
\hline $3 \mathrm{bb}$ & $\begin{array}{l}\text { Funkcionar: Goljufal si, da bi zmagal, in uporabljal kontrarevolucionarne } \\
\text { metode. Priznaj, da si kontrarevolucionar. } \\
\text { Alan Ford: Ampak jaz sem } \\
\text { kontrakontrakontrakontrakontrakontrarevolucionar! }\end{array}$ \\
\hline $3 \mathrm{cc}$ & $\begin{array}{l}\text { Funkcionar: Kontrakontra... poglejmo, štiri, pet, šest }{ }^{12} \text {, aha, v redu. } \\
\text { Alan Ford: Res?!? }\end{array}$ \\
\hline
\end{tabular}

${ }^{11}$ Najverjetneje napačen prevod iz italijanskega izraza 'granita'.

${ }^{12}$ Spet šteje na prste. 
Že hiter pregled zgornje razpredelnice pokaže, da je mest, kjer bi prevod vsebinsko odstopal od izvirnika, zelo malo, še ta so vezana na primere lastnih imen, npr. pri 3č: Cenoslovatija (Tzenoslovatiya), ki v izvirniku aludira na Čehoslovaško, oziroma na njeno sovjetsko invazijo leta 1968, na kar nakazuje tudi uporabljena "šala" preizkušanja novih tankov tako, da se jih "pošlje v Cenoslovatijo«. Čehoslovaška je kot država razpadla leta 1992, v času izida analiziranega prevoda ni več obstajala, kar je bilo najbrž med razlogi za odločitev, da se jo kot referenco izbriše. Podobna situacija je pri 3k: šampanjec Perrazzoni, ki bi sicer lahko predstavljal tipičen primer kapitalistične dekadence, je $\mathrm{v}$ prevodu nadomeščen $\mathrm{z}$ Žumberačko vodico (ta kot dejanski izdelek sicer ne obstaja) najbrž bolj iz razlogov razumljivosti oz. prepoznavnosti kot pa zato, ker bi prevajalec razmišljal o potencialnih ideoloških implikacijah izvirne reference.

Analizirano besedilo je polno ideološko zaznamovanih mest, ki se, kot je v predgovoru zapisal Magnus, neusmiljeno norčujejo iz realsocializmov sovjetskega tipa; vsa ta mesta so prevedena praktično dobesedno in tudi v prevodu učinkovito ohranjajo svojo satirično ost (glej npr. $3 \mathrm{~b}-3 \mathrm{j}, 3 \mathrm{o}-3 \mathrm{v}, 3 \mathrm{z}-3 \mathrm{cc})$. Predstavljamo si lahko, da bi bil takšen prevod, kljub drugačni politični usmeritvi SFRJ od sovjetske, težko objavljen v povsem necenzurirani obliki. Hkrati lahko zaradi odsotnosti kakršnekoli (samo)cenzure potencialno spornih mest, predvsem pa povsem drugačni prevajalski strategiji - dobesednemu namesto za Brixyja značilnemu svobodnemu prevodu in prirejanju izvirnika (na kar kaže tudi praktično nikakršno odstopanje med prevodoma italijanskega izvirnika in hrvaškega prevoda) - sklepamo, da avtor tega prevoda ni Brixy, pač pa neki drugi (neimenovani) prevajalec, četudi je Brixy v kolofonu prevoda te epizode kot prevajalec poimensko naveden. To dodatno podkrepi kronološko sosledje izdaj epizode: Brixy je namreč umrl leta 1984, epizoda Formule pa je bila po dostopnih podatkih prvič objavljena leta 1990.

\section{Sklep}

V članku smo opravili primerjalno analizo italijanskega izvirnika in hrvaškega prevoda treh izbranih epizod stripa Alan Ford. Analizirali smo ponatisnjene prevode v seriji Alan Ford Klasik, pri katerih je kot prevajalec naveden Nenad Brixy. Pri prevodu prvih dveh analiziranih epizod, Ucviljeni diktator in (Ne) glasajte za Notaxa, sklepamo, da gre z manjšimi spremembami za ponatis prvega Vjesnikovega (nedvomno Brixyjevega) prevoda, pri tretji epizodi, ki je bila prevedena in objavljena šele kasneje, pa tega ne moremo trditi, saj nam prevoda $v$ trojni številki ni uspelo najti. Tako smo analizirali dostopno različico, objavljeno v 
seriji Alan Ford Klasik in na podlagi prevajalskih strategij ugotavljali, ali je tudi ta prevod Brixyjev.

Analiza je pokazala, da je Brixy prevajal razmeroma svobodno in ideološke reference $v$ izvirniku tudi vsebinsko prirejal. Niso pa ta mesta edina mesta priredbe, saj je za njegov prevod v celoti značilno precejšnje odstopanje od nekaterih izhodiščnih formulacij, najverjetneje $\mathrm{z}$ namenom potenciranja komičnosti in farsičnosti izvirnika. Iz razlike $\mathrm{v}$ prevajalski strategiji med prvima dvema in tretjim analiziranim prevodom lahko sklepamo, da avtor tretjega prevoda ni Nenad Brixy.

Analiza jezika izvirnika pokaže, da je jezik tudi v izvirniku precej formalen, tudi pri izjavah tajnih agentov kot glavnih likov, in na določenih mestih prav tako prehaja $\mathrm{v}$ bolj formalne lege, torej komični kontrapunkt med verbalnimi in vizualnimi elementi ter njihovim sociolektom ni značilen le za prevod, pač pa tudi za izvirnik. Glede na silno priljubljenost ter posledično različne izdaje in ponatise prevodov Alana Forda, ki po skopih dostopnih virih kažejo, da so bili nekateri prevodi kasneje redigirani, bi bilo treba za dopolnitev ugotovitev pridobiti besedila prevodov $\mathrm{v}$ vseh izdajah, jih analizirati in ugotavljati morebitne razlike v prevajalski strategiji in avtorjih prevoda. To velja tako za tri epizode, analizirane v tem članku, kot tudi za siceršnje prevode stripa.

Razlogi za prirejanje ideoloških referenc v prevodu so zaradi pomanjkanja virov in nedokumentiranosti samocenzure težje dokazljivi, zato ne moremo z gotovostjo ugotoviti, ali gre za samocenzuro ali za individualno prevajalčevo strategijo, ki pa ni pojasnjena. Kljub temu podatki o izhajanju stripa, ki smo jih uspeli pridobiti, ter analiza virov napeljujejo $\mathrm{k}$ sklepu, da so omenjeni posegi prej posledica samocenzure kot prevajalčeve idiosinkrazije. Vsem izpuščenim in šele kasneje prevedenim in objavljenim epizodam kot tudi prirejenim mestom $\mathrm{v}$ prevodih, ki jih je nesporno opravil Brixy, je namreč skupna njihova ideološka vsebina, ki bi lahko sprožila politični ali cenzurni odziv oblasti. Pri tem je značilno, da so prirejene vse ideološke reference, ki bi lahko kakorkoli »kvarile ljudstvo«: ne le tiste, ki kritizirajo realsocializme, pač pa tudi tiste, ki govorijo o politični in ekonomski izprijenosti kapitalizma. Cenzura v SFRJ je bila razmeroma mehka in ambivalentna, z nejasnimi mejami med dovoljenim in nedovoljenim, kar je lahko odvračalo od nepotrebnega tveganja ali provociranja oblasti, Brixy pa si je v dvojni vlogi prevajalca in vplivnega urednika pri Plavem vjesniku gotovo prizadeval za kontinuirano izhajanje stripa, ki ga je sam predlagal v objavljanje. Za dokazovanje druge teze, da so bile spremembe individualno prevajalčeve, ki je sicer ne moremo povsem izključiti, bi morali sistematično analizirati bistveno večji korpus Brixyjevih prevodov Alana Forda. 


\section{LITERATURA}

Alan Ford: piratska izdanja. Splet. 27. 8. 2020. <http://skab612.com/index.php?site=bsp_ popisi\&oznaka $=$ AFP\&stranica $=1>$

Alan Ford: cenzura. Splet. 27. 8. 2020. <http://skab612.com/AlanFord/af_cenzura.html>.

Baker, Mona. "Reframing Conflict in Translation«. Critical Readings in Translation Studies. Ur. Mona Baker. London: Routledge, 2010. 113-129.

Bourdieu, Pierre. Language and Symbolic Power. Cambridge: Polity Press, 1991.

Buh, Aleksander. Zasebna komunikacija, september in oktober 2017.

Crespo, Itziar. Translating in a Nationalistic Context: Censorship in Translation under Franco. Manchester: University of Manchester, 1999.

Džamić, Lazar. Cvjećarnica u Kući cvijeća: kako smo usvojili i živeli Alana Forda. Zagreb: Jesenski i Turk, 2012.

Gržina, Hrvoje. »Semiotička analiza mediju stripa svojstvenih vizualnih elemenata u Alanu Fordu Maxa Bunkera i Magnusa". Medijske studije 5.10 (2014): 19-35.

Hatim, Basil in Ian Mason. The Translator as Communicator. London: Routledge, 1997.

Kuhiwczak, Piotr. "Translation Studies Forum: Translation and censorship«. Translation Studies 4.3 (2011): 358-373.

Lehmann, Eric. Le ali del potere: la propaganda aeronautica nell'Italia fascista. Torino: UTET, 2010.

Pokorn Kocijančič, Nike. Post-Socialist Translation Practices: Ideological Struggle in Children's Literature. Amsterdam; Philadelphia: John Benjamins, 2012.

Mason, Ian. "Discourse, Ideology and Translation«. Critical Readings in Translation Studies. Ur. Mona Baker. London: Routledge, 2010. 84-95.

Horvat, Marjan. "Lazar Džamić: pisec knjige o fenomenu stripa Alan Ford, ki je obnorel samo nekdanjo Jugoslavijo: zakaj samo njo?: kulisa za razumevanje balkanske mentalitete«. Mladina 9 (27. februar 2015): 80-81..

Patruno, Camilla. »Alan Ford: il piu' amato dagli Slavi«. Splet. 27. 8. 2020. <http:// www.ubcfumetti.com/italia/?12702>

Rakezić, Saša [Aleksandar Zograf]. "Alan Ford: Big in the Balkans«. Splet. 27. 8. 2020. <http://skab612.com/AlanFord/af_tekst11.html>

Rundle, Christopher. Publishing Translation in Fascist Italy. Bern: Peter Lang, 2010.

Secchi, Luciano [Max Bunker]. Alan Ford: Una gita a San Guerreta. Milano: Mondadori, 2014.

Secchi, Luciano [Max Bunker]. Alan Ford: Un voto per Notax. Milano: Mondadori, 2014.

Secchi, Luciano [Max Bunker]. Alan Ford: Formule. Milano: Mondadori, 2014.

Secchi, Luciano [Max Bunker], in Roberto Raviola [Magnus]. Formule. Prevedel Nenad Brixy. Zagreb: Strip-agent, 2004.

Secchi, Luciano [Max Bunker], in Roberto Raviola [Magnus]. Ucviljeni diktator. Prevedel Nenad Brixy. Zagreb: Strip-agent, 2004.

Secchi, Luciano [Max Bunker], in Roberto Raviola [Magnus]. (Ne) glasajte za Notaxa. Prevedel Nenad Brixy. Zagreb: Strip-agent, 2004.

Seruya, Teresa in Maria Lin Moniz, ur. Translation and Censorship in Different Times and Landscapes. Newcastle upon Tyne: Cambridge Scholars Publishing, 2008.

Sherry, Samantha. Censorship in Translation in the Soviet Union: The Manipulative Rewriting of Howard Fast's Novel The Passion of Sacco and Vanzetti. Slavonica 16.1 (2010): 1-14.

Sherry, Samantha. Discourses of Regulation and Resistance: Censoring Translation in the Stalin and the Khruschev Era in the Soviet Union. Edinburgh: Edinburgh University Press, 2015. 
Skubic, Andrej E. Obrazi jezika. Ljubljana: Študentska založba, 2006.

Sturge, Kate. "A Danger and a Veiled Attack: Translating into Nazi Germany«. The Practices of Literary Translation: Constraints and Creativity. Ur. Jean Boase-Beier in Michael Holman. Manchester: St Jerome Publishing, 1999. 135-146.

Tan, Zaixi. SCensorship in translation: The case of the People's Republic of China«. Neohelicon 42.1 (2015): 313-339.

Tymoczko, Maria. "Censorship and Self-Censorship in Translation: Ethics and Ideology, Resistance and Collusion«. Translation and censorship. Ur. Eiléan Ní Chuilleanáin, Cormac Ó Cuilleanáin in David Parris. Dublin: Four Courts Press, 2009. 24-45.

Venuti, Lawrence. The Translator's Invisibility. London: Routledge, 1995.

\section{Translating Ideological References: The Case of Alan Ford}

Keywords: literary translation / adaptation / censorship / self-censorship / ideology / Italian literature / comics / Alan Ford / translations to Croatian

The article analyzes the translation of ideological references in three episodes of the Italian comic book Alan Ford. It was translated into Croatian by Nenad Brixy, translator, writer and editor at the Vjesnik newspaper in Zagreb, who also proposed the comic book for publication in Croatian. Brixy's translation, which became hugely popular in the former Yugoslavia primarily for its humor, is relatively free, and more of a cultural adaptation than a faithful translation. The analysis of the three selected translated episodes shows that all ideological references in the two episodes which were published in the same chronological order as in the Italian edition were adapted while the translation of the third episode, Formule, which was published only later, is significantly more literal and cannot be attributed to Brixy even though he is credited as the translator of this episode as well.

1.01 Izvirni znanstveni članek / Original scientific article

UDK 81'255.4:741.52

821.131.1.09:81'25=163.42

DOI: https://doi.org/10.3986/pkn.v43.i2.09 